\title{
EFEKTIVITAS MUSIK KLASIK UNTUK MENCIPTAKAN SUASANA HATI POSITIF PADA SISWA SMP SEMEN GRESIK
}

\author{
Anindita Vidyawati ${ }^{1}$, Muhimmatul Hasanah ${ }^{2}$ \\ Universitas Muhammadiyah Gresik ${ }^{1}$, Institut Pesantren Sunan Drajat Lamongan ${ }^{2}$
}

\begin{abstract}
Abstrak
Penelitian ini bertujuan untuk mengetahui efektivitas musik klasik untuk menciptakan suasana hati positif. Subyek dalam penelitian ini menggunakan siswa SMP Semen Gresik kelas 8 yang memiliki tingkat suasana hati rendah yang berjumlah 14 orang. Pengumpulan data menggunakan kuesioner yang disusun dengan skala Likert. Penelitian ini menggunakan desain eksperimen semu. Jenis pengambilan sampel yang digunakan yaitu sampling purposive. Analisis data dalam penelitian ini menggunakan analisis uji Mann -Whitney. Hasil analisis data menunjukkan tidak ada perbedaan yang signifikan antara perubahan suasana hati kelompok eksperimen dan kelompok kontrol, dengan selisih nilai yang diperoleh $\mathrm{Z}=-1.086$; dan $\mathrm{p}=0.277$ ( $\mathrm{p}<0,05)$ yang mengindikasikan bahwa tidak ada efektivitas musik klasik untuk menciptakan suasana hati positif pada siswa. Musik klasik dapat menciptakan suasana hati positif pada siswa dengan kondisi lingkungan maupun ruangan yang kondusif.
\end{abstract}

Kata kunci: Musik Klasik, Suasana Hati.

\begin{abstract}
This research aims to determine the effectiveness of classical music to create a positive mood. The subjects in this study used $8^{\text {th }}$ grade students of Semen Gresik Middle School who had a low mood level of 14 people. Data collection uses questionnaires arranged in a Likert scale. This study uses a Quasiexperimental design. The type of sampling used is purposive sampling. Data analysis in this study used the Mann- Whitney test analysis. The result of data analysis showed no significant difference between mood changes in the experimental group and the control group, with the difference in values obtained $\mathrm{Z}=-1.086$; and $\mathrm{p}=0.277$ ( $\mathrm{p}<0,05)$ indicating that there was no effectiveness of classical music to create a positive mood to students. Classical music can create a positive mood for students with conducive environment and room conditions.
\end{abstract}

Keywords: Classical Music, Mood.

\footnotetext{
12aninditavidyawati@gmail.com, ${ }^{2}$ hima_hasanah@yahoo.com Fakultas Psikologi Universitas Muhammadiyah Gresik Jalan Sumatra No 101 Gresik ${ }^{2}$ Prodi Bimbingan Konseling Islam Institut Pesantren Sunan Drajat Lamongan Komplek Po.Pes Sunan Drajat Banjarwati Paciran Lamongan
} 


\section{Pendahuluan}

Menurut Winkel, belajar adalah suatu aktivitas mental atau psikis yang berlangsung dalam interaksi aktif dengan lingkungan yang menghasilkan perubahan-perubahan dalam pengetahuan, pemahaman, keterampilan, nilai, dan sikap (Supradewi, 58: 2010). Untuk mendapatkan hasil yang maksimal dalam suatu proses pembelajaran, maka perlu didukung proses belajar yang efektif. Menciptakan lingkungan belajar yang menyenangkan dan mendukung serta menyediakan suasana ruang kelas yang nyaman dari segi penerangan, tempat duduk, beberapa hiasan di dalam ruangan atau seperti menggunakan musik sebagai bagian dari media pembelajaran. Dengan begitu siswa dapat lebih banyak belajar jika situasi belajarnya menyenangkan, memuaskan, menantang, ramah, dan mereka dapat memberikan berpendapat dalam pembuatan keputusan. Anak juga lebih menikmati belajar keterampilan kognitif bila disertai pengalaman musikal. Keterampilan kognitif, seperti klasifikasi, menata urutan, pengertian ruang, dan hubungan waktu dapat ditingkatkan dengan mendengarkan musik (Djohan, 2016: 140).

Supradewi (2010: 67) menjelaskan bahwa penelitian-penelitian yang telah dilakukan para peneliti, tampak bahwa musik memang dapat mempengaruhi gelombang otak dan neurofisiologis tubuh manusia yang bila digunakan dalam proses belajar memberikan hasil yang positif. Selain itu, musik dapat lebih meningkatkan konsentrasi, merekatkan ingatan materi pelajaran, membuat suasana lebih rileks dan gembira, dan akhirnya dapat mempengaruhi performa untuk mendapatkan nilai tes yang lebih tinggi.

Penelitian yang telah dilakukan oleh Hidayat (2011) membuktikan pengaruh musik klasik terhadap daya tahan konsentrasi dalam belajar pada mahasiswa. Pemberian musik klasik dapat meningkatkan daya tahan konsentrasi mahasiswa dalam belajar. Musik klasik yang digunakan mempunyai tempo rendah dan pitch antara 70-80 bpm (bit per menit), berupa lagu instrumental yang tidak memiliki kata-kata atau lirik lagu, dan bukan merupakan musik instrumental yang berasal dari lagu yang mempunyai lirik. Terdapat 11 judul musik yang diperdengarkan seperti Fur Elise dan Adagio gubahan L.V. Beethoven, Water Music oleh Frederic Handel. Musik klasik dapat menciptakan kondisi jiwa dan fisik yang rileks, dengan begitu dapat memudahkan individu untuk mempertahankan daya konsentrasinya.

Pada observasi tanggal 13 Desember 2016, dilakukan di ruang kelas Psikologi yang sedang melaksanakan kegiatan belajar mengajar suatu mata kuliah. Dosen memberi tugas berupa diskusi kelompok. Setelah mahasiswa selesai membentuk beberapa kelompok, kemudian sesi diskusi dimulai dan dosen memutarkan musik kepada mahasiswa, salah satu contoh lagu yang diputarkan saat itu adalah instrumental dari Ost. Frozen - Let It Go. Awalnya beberapa 
mahasiswa sempat heran karena dosen memutarkan musik saat perkuliahan sedang dimulai. Sedangkan pada umumnya, situasi belajar selalu gambarkan dengan suasana ruangan yang tenang dan tidak berisik. Setelah beberapa menit diskusi berjalan disertai dengan musik, mahasiswa nampak menikmati, suasana kelas juga tampak tenang dan diskusi berjalan dengan baik.

Semakin tinggi mutu kegiatan belajar siswa, diharapkan semakin baik hasil belajarnya dan semakin banyak masalah belajar yang dialami siswa memungkinkan rendah perolehan hasil belajarnya. Tentunya jumlah masalah belajar pada siswa akan terus meningkat dari tahun ke tahun. Seperti yang telah dijelaskan pada latar belakang di atas, banyak hal yang mempengaruhi sikap belajar siswa di kelas tidak hanya dari faktor internal siswa itu sendiri, tetapi juga faktor ekstenal yang timbul dari luar individu seperti sekolah maupun keluarga atau rumah.

Musik dapat dikatakan sebagai penghayatan isi hati manusia yang diungkapkan dalam bentuk bunyi yang teratur dengan melodi atau ritme serta mempunyai unsur atau keselarasan yang indah. Istilah musik dikenal dari bahasa Yunani yaitu Musike. Musike berasal dari perkataan muse-muse, yaitu sembilan dewa-dewa Yunani di bawah dewa Apollo yang melindungi seni dan ilmu pengetahuan. Dalam metodologi Yunani Kuno mempunyai arti suatu keindahan yang terjadinya berasal dari kemurahan hati para dewa-dewa yang diwujudkan sebagai bakat. Kemudian pengertian itu ditegaskan oleh Pythagoras, bahwa musik bukanlah sekedar hadiah (bakat) dari para dewa-dewi, tetapi musik terjadi karena akal budi manusia dalam membentuk teori-teori (Widhyatama, 2012: 01).

Menurut Djohan (2016) Musik adalah produk pikiran. Maka elemen vibrasi dalam bentuk frekuensi, amplitudo, dan durasi belum menjadi musik, sampai semua itu di tranformasi secara neurologis dan di interpretasikan melalui otak menjadi pitch (nada-harmoni), timbre (warna suara), dinamika (keras-lembut), dan tempo (cepat-lambat). Transformasi ke dalam musik dan respon manusia (perilaku) merupakan hal yang unik untuk dikenali (kognisi). Musik juga memiliki dimensi kreatif dan memiliki bagian-bagian yang identik dengan proses belajar secara umum. Dalam musik terdapat analogi melalui persepsi, visual, auditori, antisipasi, induktif-deduktif, memori, konsentrasi, dan logika.

Musik dapat membantu menutupi "kebisingan samar" (dengung lampu, suara di ruangan sebelah, dan lain-lain) dan menciptakan lingkungan mendukung yang berkesinambungan. Atur volume musik pada tingkat yang dapat didengar hanya saat ruangan sunyi. Musik seperti bunyi piano, cello, dan biola alto juga dapat menjadi pilihan untuk merelaksasikan siswa setelah situasi penuh stres di dalam kelas (De Porter \& Mike Hernaki, 2008: 74).

Musik klasik dapat berarti musik simfoni, musik ruangan, opera, dan konserto. Namun, musik dapat berarti juga musik yang mempunyai kualitas abadi. 
Penulis musik klasik yang terkenal, dalam sejarah, diantaranya Bach, Mozart, Beethoven, dan Schubert (Harry Sulastianto dkk, 2006: 45).

Kemampuan dari musik Mozart atau yang sekarang dikenal dengan Efek Mozart (Mozart Effect), telah meningkatkan kesadaran ruang dan kecerdasan untuk beberapa waktu; kekuatannya untuk meningkatkan konsentrasi dan kemampuan bicara para pendengarnya; dan kecenderungannya untuk memungkinkan lompatan cukup jauh dalam keterampilan membaca dan berbahasa di kalangan anak-anak yang menerima instruksi musik secara teratur. Tidak dapat disangkal bahwa musik memberikan lebih daripada sekedar yang kita dengar dengan telinga. Apabila dimanfaatkan dengan bijak, musik dapat menciptakan sebuah bunyi-bunyian yang sehat dan menggairahkan bagi diri sendiri, keluarga dan juga meningkatkan pertumbuhan anak-anak (Campbell, 2002: 10).

Menurut Kartini Kartono (1996: 92) Suasana hati adalah kondisi perasaan yang berkesinambungan, dicirikan dengan selalu timbulnya perasaan-perasaan senang, atau tidak senang. Sebab-sebab dari suasana hati itu pada umumnya ada dalam bawah sadar kita; namun adakalanya juga disebabkan oleh faktor jasmaniah.

Menurut Watson (2000: 04), "Moods are transient episodes of feeling or affect", yang artinya suasana hati adalah episode peralihan dari perasaan atau emosi. Suasana hati seseorang dapat berlangsung dalam jangka pendek, beberapa jam, atau beberapa hari. Suasana hati dipengaruhi oleh banyak kejadian tak terduga. Menurut Robbins \& Judge (2012: 99) ciri-ciri dari suasana hati yaitu:

a. Penyebabnya sering kali umum dan tidak jelas

b. Berakhir lebih lama dari emosi (jam atau hari)

c. Lebih umum (dua dimensi utama afek positif dan afek negatif yang terdiri berbagai emosi spesifik)

d. Biasanya tidak diindikasikan oleh ekspresi yang jelas

e. Bersifat kognitif

Menurut Lane (2007: 264), terdapat delapan dimensi suasana hati memberikan penilaian yang seimbang dari suasana hati positif dan suasana hati negatif. Antara lain:

a. Dimensi suasana hati positif :

- Suasana hati semangat terdiri dari: Waspada dan Penuh Semangat

- Suasana hati ketenangan terdiri dari: Tenang dan Santai

- Suasana hati kebahagiaan terdiri dari: Riang dan Bahagia

b. Dimensi suasana hati negatif :

- Suasana hati marah terdiri dari: Pemarah dan Marah

- Suasana hati bingung terdiri dari: Campur aduk (Kebingungan) dan Ketidakpastian

- Suasana hati depresi terdiri dari: Depresi dan Putus asa 
- Suasana hati kelelahan terdiri dari: Lusuh dan Lelah

- Suasana hati ketegangan terdiri dari: Cemas dan Panik

Penelitian yang telah dilakukan oleh Bower mengemukakan bahwa ingatan akan jauh lebih baik apabila suasana hati pada saat belajar cocok dengan suasana hati pada waktu mengingat. Begitu juga apabila pada saat proses belajar diperdengarkan musik sebagai pengiring belajar, dimana musik akan berperan untuk mengubah suasana hati pendengarnya senang atau sedih. Musik tidak hanya mengubah suasana hati para pelajarnya tetapi juga lingkungan belajar. Musik dalam proses belajar dapat digunakan untuk: a) meningkatkan semangat, b) merangsang pengalaman, c) menumbuhkan relaksasi, d) meningkatkan fokus, e) membina hubungan, f) menentukan tema untuk hari itu, g) memberi inspirasi, h) bersenang-senang (De Porter \&Mike Hernaki, 2008: 77).

Mendengarkan musik, dapat membuat perasaan lebih tenang dan lebih lepas. Apabila musik klasik masuk melalui telinga, kemudian menggetarkan gendang telinga, mengguncang cairan di telinga bagian dalam, serta menggetarkan sel-sel berambut di dalam koklea untuk selanjutnya melalui saraf koklearis menuju ke otak. Musik akan diterima langsung oleh talamus, yaitu suatu bagian otak yang mengatur emosi, sensasi, dan perasaan, tanpa lebih dulu dicerna oleh bagian otak yang berpikir mengenai baik-buruk, maupun inteligensia. Kedua, melalui hipotalamus mempengaruhi struktur basal forebrain termasuk sistem limbik, dan ketiga, melalui akson neuron secara difus mempengaruhi neokorteks. Hipotalamus merupakan pusat saraf otonom yang mengatur fungsi pernapasan, denyut jantung, tekanan darah, pergerakan otot usus, fungsi endoktrin, memori dan lain-lain (Sirait, 2006). Dengan kondisi perasaan yang lebih tenang dan lebih lepas yang demikian memungkinkan untuk membuat suasana hati siswa saat belajar lebih baik.

\begin{tabular}{|c|c|c|c|}
\hline $\begin{array}{l}\underline{\text { MUSIK }} \\
\underline{\text { KLASIK }}\end{array}$ & $\because \cdot$ & $\begin{array}{l}\text { Telinga } \rightarrow \text { gendang } \\
\text { telinga } \rightarrow \text { koklea } \rightarrow \\
\text { saraf koklearis } \rightarrow \\
\text { otak. } \\
\text { Otak } \rightarrow \text { thalamus } \rightarrow \\
\text { hipotalamus } \rightarrow \text { akson } \\
\text { neuron } \rightarrow \text { neokorteks }\end{array}$ & $\begin{array}{l}\text { Suasana Hati : } \\
\text { - Suasana Hati Positif } \\
\checkmark \text { Semangat } \\
\checkmark \text { Ketenangan } \\
\checkmark \text { Kebahagiaan }\end{array}$ \\
\hline
\end{tabular}

Gambar 1. Skema Keterkaitan antara Musik Klasik dan Suasana Hati

\section{Metode Penelitian}

Penelitian ini menggunakan desain penelitian eksperimen semu (Quasi Experiment Design). Rancangan penelitian yang digunakan dalam penelitian ini 
adalah Control Group Design yang merupakan desain eksperimen dengan melakukan pengukuran atau observasi awal sebelum dan sesudah perlakuan diberikan pada kelompok eksperimen dan kelompok kontrol (Latipun, 2006: 107).

Tabel 1. Skema Desain Penelitian

\begin{tabular}{cccc}
\hline Kelompok & $\begin{array}{c}\text { Pengukuran } \\
\text { (Pretest) }\end{array}$ & Perlakuan & $\begin{array}{c}\text { Pengukuran } \\
\text { (Posttest) }\end{array}$ \\
\hline $\mathrm{KE}$ & $\mathrm{O}_{1}$ & $\mathrm{X}$ & $\mathrm{O}_{2}$ \\
$\mathrm{KK}$ & $\mathrm{O}_{1}$ & $-\mathrm{X}$ & $\mathrm{O}_{2}$ \\
\hline
\end{tabular}

Alat ukur yang akan digunakan oleh peneliti adalah skala Likert. Interpretasi hasil pengukuran yaitu semakin tinggi skor hasil pengukuran maka menunjukkan kondisi suasana hati yang positif. Sebaliknya, semakin rendah skor hasil pengukuran maka menunjukkan kondisi suasana hati yang negatif.

Alat-alat yang digunakan untuk pemutaran musik klasik adalah laptop dan pengeras suara (loudspeaker) yang diletakkan di bagian tengah ruangan. Musik klasik diputar melalui laptop dan diperdengarkan melalui pengeras suara (loudspeaker). Saat penelitian berlangsung 10 judul musik tersebut diputar secara bergantian dengan durasi waktu 30 menit selama 5 hari. Musik klasik yang digunakan dalam penelitian adalah: Turkish March oleh Mozart, Four Seasons (Winter) oleh Antonio Vivaldi, Symphony No. 40 in G minor oleh Mozart, Minuet In $G$ Major oleh Bach, The Swan Lake oleh Tchaikovsky, Dance Of The Sugarplum Fairy oleh Tchaikovsky, Moonlight Sonata oleh Beethoven, Clarinet Concerto In A Major oleh Mozart, Canon in D Major oleh Johann Pachelbel, dan Fur Elise oleh Beethoven.

\section{Hasil dan Pembahasan}

Deskripsi data penelitian yang diperoleh dari hasil pretest dan posttest skala suasana hati pada kelompok eksperimen dan kelompok kontrol dapat dilihat pada tabel di bawah ini yang merupakan rerata skor pada kelompok eksperimen dan kelompok kontrol.

Tabel 2. Skor Rata-rata Pretest Dan Posttest Pada Kelompok Eksperimen Dan Kelompok Kontrol

\begin{tabular}{lllll}
\hline & \multicolumn{2}{l}{ Kelompok Eksperimen } & \multicolumn{2}{l}{ Kelompok Kontrol } \\
\cline { 2 - 5 } & Pretest & Posttest & Pretest & Posttest \\
\hline Rerata & $\begin{array}{l}67,6 \\
\text { Empirik }\end{array}$ & $\begin{array}{l}78,7 \\
\text { (Rendah) }\end{array}$ & $\begin{array}{l}69,4 \\
\text { (Rendah) }\end{array}$ & $\begin{array}{l}72,9 \\
\text { (Rendah) }\end{array}$
\end{tabular}

Setelah melihat rata-rata skor suasana hati saat pretest dan posttest pada kelompok eksperimen dan kelompok kontrol, dapat disimpulkan bahwa pada kelompok eksperimen terjadi peningkatan suasana hati saat posttest dibandingkan 
saat prestest. Kemudian tingkat suasana hati pada masing-masing siswa saat prestest dan posttest juga dapat dilihat pada tabel berikut.

Tabel 3. Skor Rata-rata Pretest Dan Posttest Pada Kelompok Eksperimen Dan Kelompok Kontrol

\begin{tabular}{|c|c|c|c|c|c|}
\hline \multirow{2}{*}{ Sby } & \multicolumn{2}{|c|}{ Kel. Eksperimen } & \multirow{2}{*}{ Sby } & \multicolumn{2}{|c|}{ Kel. Kontrol } \\
\hline & Pretest & Posttest & & Pretest & Posttest \\
\hline 1 & $\begin{array}{c}75 \\
\text { (Rendah) }\end{array}$ & $\begin{array}{c}84 \\
\text { (Sedang) }\end{array}$ & 1 & $\begin{array}{c}73 \\
\text { (Rendah) }\end{array}$ & $\begin{array}{c}89 \\
\text { (Tinggi) }\end{array}$ \\
\hline 2 & $\begin{array}{c}74 \\
\text { (Rendah) }\end{array}$ & $\begin{array}{c}64 \\
\text { (Rendah) }\end{array}$ & 2 & $\begin{array}{c}74 \\
\text { (Rendah) }\end{array}$ & $\begin{array}{c}82 \\
\text { (Sedang) }\end{array}$ \\
\hline 3 & $\begin{array}{c}73 \\
\text { (Rendah) }\end{array}$ & $\begin{array}{c}77 \\
\text { (Sedang) }\end{array}$ & 3 & $\begin{array}{c}71 \\
\text { (Rendah) }\end{array}$ & $\begin{array}{c}77 \\
\text { (Sedang) }\end{array}$ \\
\hline 4 & $\begin{array}{c}60 \\
\text { (Rendah) }\end{array}$ & $\begin{array}{c}61 \\
\text { (Rendah) }\end{array}$ & 4 & $\begin{array}{c}70 \\
\text { (Rendah) }\end{array}$ & $\begin{array}{c}61 \\
\text { (Rendah) }\end{array}$ \\
\hline 5 & $\begin{array}{c}68 \\
\text { (Rendah) }\end{array}$ & $\begin{array}{c}86 \\
\text { (Sedang) }\end{array}$ & 5 & $\begin{array}{c}70 \\
\text { (Rendah) }\end{array}$ & $\begin{array}{c}70 \\
\text { (Rendah) }\end{array}$ \\
\hline 6 & $\begin{array}{c}65 \\
\text { (Rendah) }\end{array}$ & $\begin{array}{c}84 \\
\text { (Sedang) }\end{array}$ & 6 & $\begin{array}{c}60 \\
\text { (Rendah) }\end{array}$ & $\begin{array}{c}58 \\
\text { (Rendah) }\end{array}$ \\
\hline 7 & $\begin{array}{c}58 \\
\text { (Rendah) }\end{array}$ & $\begin{array}{c}95 \\
\text { (Tinggi) }\end{array}$ & 7 & $\begin{array}{c}68 \\
\text { (Rendah) }\end{array}$ & $\begin{array}{c}73 \\
\text { (Rendah) }\end{array}$ \\
\hline
\end{tabular}

Hasil uji Mann-Whitney menunjukkan selisih nilai pretest dan posttest antara kelompok eksperimen dan kelompok control dengan nilai $\mathrm{Z}=-1.086$; dan $\mathrm{p}=0.277$ (taraf signifikansi 5\%). Berdasarkan hasil tersebut maka Ho diterima dan Ha ditolak. Jadi, tidak ada efektivitas musik klasik untuk menciptakan suasana hati positif pada siswa SMP Semen Gresik.

Dari hasil analisis pada setiap subjek pada kelompok eksperimen, dapat diketahui bahwa musik klasik mempunyai pengaruh pada masing-masing subjek kelompok eksperimen. Analisis subjek pada kelompok eksperimen pada saat mendengarkan musik klasik menunjukkan kondisi subjek yang merasa lebih tenang, rileks, segar, konsentrasi menjadi baik/fokus, senang, bersemangat, dan badan menjadi ringan.

Murrock (2005: 05) menyatakan bahwa musik memiliki kemampuan untuk membuat pendengarnya menjadi senang, sedih, antusias, gembira, murung, merangsang (mendorong), memulihkan atau menguatkan. Kelebihan musik adalah dapat merubah suasana hati antara sadar dan tidak sadar. Hal ini dapat diketahui 
dari pernyataan dari salah satu subjek yang mengatakan bahwa saat mendengarkan musik klasik, subjek membayangkan ada banyak orang dan ada yang sedang berdansa disana, dan ada juga orang yang sedang bermain musik piano.

Kemudian yang dirasakan setelah mendengarkan musik klasik selama 30 menit, mereka merasa senang, rileks, mengantuk, bersemangat, mampu mendengarkan guru di kelas, dan memperbaiki suasana hati (mood) yang awalnya ingin marah lalu setelah mendengarkan musik menjadi lebih tenang. Berikut ini tabel yang menunjukkan suasana hati yang dirasakan oleh subjek pada kelompok eksperimen setelah mendengarkan musik klasik.

Tabel 4. Suasana Hati Yang Dirasakan Oleh Kelompok Eksperimen Setelah Mendengarkan Musik Klasik

\begin{tabular}{|c|c|}
\hline Subjek & Jawaban \\
\hline 1 & $\begin{array}{l}\text { - Saya merasa rileks setelah mendengarkan musik } \\
\text { - Saya mengetahui salah satu musik klasik tersebut tetapi } \\
\text { yang lainnya tidak } \\
\text { - Saya merasa semangat setelah mendengarkan musik klasik } \\
\text { - Saya teringat saat main game dancing line, karena ada } \\
\text { beberapa musik yang terdengar mirip } \\
\text { - Saat mendengarkan musik saya merasa mengantuk, } \\
\text { terkadang juga tidak }\end{array}$ \\
\hline 2 & $\begin{array}{l}\text { - Saya merasa tenang dan senang sesudah mendengarkan } \\
\text { musik klasik } \\
\text { - Saya merasa tubuh menjadi lebih ringan } \\
\text { - Saya merasa tenang ketika mengikuti pelajaran }\end{array}$ \\
\hline 3 & $\begin{array}{l}\text { - Saya setelah mendengarkan musik klasik lebih segar dan } \\
\text { lebih tenang } \\
\text { - Ketika mendengarkan musik klasik, mood saya yang ingin } \\
\text { marah kemudian hilang menjadi mood yang lebih tenang } \\
\text { dari sebelumnya } \\
\text { - Ketika mendengarkan musik klasik saya merasa } \\
\text { mengantuk dan ingin tidur } \\
\text { - Saya baru mengetahui bahwa musik klasik itu seperti yang } \\
\text { saya dengarkan } \\
\text { - Terdapat hanya satu lagu yang pernah saya dengarkan, } \\
\text { sedangkan yang lain belum pernah sama sekali } \\
\text { - Saat mendengarkan musik klasik, saya membayangkan } \\
\text { ada orang berdansa, dengan banyak orang disana dan ada } \\
\text { alat musik piano. } \\
\text { - Saat mendengarkan musik klasik saya sempat terfikirkan } \\
\text { konflik dengan teman tetapi hanya sebentar } \\
\text { - Merasa sebal saat ada gangguan dari luar ruangan saat } \\
\text { sedang mendengarkan musik klaisk (seperti suara genteng }\end{array}$ \\
\hline
\end{tabular}




\begin{tabular}{|c|c|}
\hline & $\mathrm{ja}$ \\
\hline 4 & $\begin{array}{l}\text { - Setelah mendengarkan musik klasik saya merasa tubuh } \\
\text { menjadi enak } \\
\text { - Setelah mendengarkan musik klasik saya tidak sering } \\
\text { mengantuk } \\
\text { - Bisa mendengarkan penjelasan guru di kelas dengan } \\
\text { tenang }\end{array}$ \\
\hline 5 & $\begin{array}{l}\text { - Saya menyukai musik klasiknya tetapi saat awal } \\
\text { mendengarkan tidak mengetahui judulnya } \\
\text { - Saya merasa mengantuk ketika mendengarkan musik } \\
\text { klasik } \\
\text { - Saya merasa lebih fresh ketika mendengarkan musik } \\
\text { klasik } \\
\text { - Saya merasa nyaman mendengarkan musik klasik }\end{array}$ \\
\hline 6 & $\begin{array}{l}\text { - Saat mendengarkan musik klasik saya merasa senang } \\
\text { - Saat saya mendengarkan musik klasik itu pikiran langsung } \\
\text { menjadi tenang } \\
\text { - Saya merasa mengantuk ketika mendengarkan musik } \\
\text { klasik }\end{array}$ \\
\hline 7 & $\begin{array}{l}\text { - Saya baru mengetahui bahwa yang saya dengarkan adalah } \\
\text { musik klasik } \\
\text { - Saya tidak mengetahui judul musik klasik tersebut tetapi } \\
\text { saya menyukai musik klasiknya } \\
\text { - Setelah mendengarkan musik klaik saya merasa lebih } \\
\text { fresh, saya juga lebih bisa fokus mendengarkan guru di } \\
\text { kelas, saya juga merasa seperti flashback ke zaman dulu } \\
\text { ketika mendengarkan musik klasik }\end{array}$ \\
\hline & $\begin{array}{l}\text { - Saat mendengarkan musik klasik subjek merasa } \\
\text { bersemangat, tenang, senang, tubuh menjadi segar, } \\
\text { nyaman, fresh, dan dapat fokus mendengarkan guru di } \\
\text { dalam kelas }\end{array}$ \\
\hline
\end{tabular}

Manfaat dari mendengarkan musik klasik ini dapat diterapkan pada pihak sekolah maupun lembaga pendidikan lainnya untuk meningkatkan suasana hati siswa maupun untuk istirahat setelah belajar selama 45 menit atau lebih. Hal ini dimaksudkan untuk mengendurkan siswa di kelas dari kejenuhan, rasa tegang, kurangnya semangat, maupun kondisi tidak nyaman/bosan di kelas dan membiarkan pikiran mereka mencerna apa yang telah mereka pelajari. Musik klasik juga dapat digunakan sebagai latar belakang saat sedang belajar maupun saat sedang mendengarkan materi dari guru di dalam kelas dan mem-filter suarasuara yang tidak diinginkan. Musik dapat diputar dengan volume rendah sehingga suara guru tetap dapat didengar oleh siswa (Lawrence, 2001: 08). 
De Porter \& Mike Hernaki (2005: 74) mengatakan bahwa ketika otak kiri bekerja, seperti mempelajari materi baru, musik akan membangkitkan reaksi otak kanan yang intuitif dan kreatif sehingga masukannya dapat dipadukan dengan keseluruhan proses. Adalah otak kanan yang cenderung untuk terganggu selama rapat, kuliah atau semacamnya, yang merupakan penyebab mengapa beberapa orang kadang-kadang melamun dan memperhatikan pemandangan ketika berniat untuk konsentrasi. Memasang musik merupakan cara efektif untuk menyibukkan otak kanan ketika sedang berkonsentrasi pada aktivitas-aktivitas otak kiri.

\section{Kesimpulan}

Hasil penelitian yang didapat setelah analisis dengan menggunakan uji Mann -Whitney menunjukkan bahwa Tidak ada efektivitas musik klasik untuk menciptakan suasana hati pada siswa SMP Semen Gresik. Hasil dari kedua kelompok tersebut, kelompok eksperimen dan kelompok kontrol, tidak memperlihatkan perbedaan yang signifikan pada kedua hasilnya, akan tetapi perbedaan antara kelompok eksperimen dan kelompok kontrol dapat dilihat dari pernyataan subjek mengenai kondisi yang dirasakan pada kelompok eksperimen setelah mendengarkan musik klasik.

\section{Daftar Pustaka}

Campbell, D. (2002). Efek Mozart Bagi Anak-Anak: Meningkatkan Daya Pikir, Kesehatan, Dan Kreativitas Anak Melalui Musik. Jakarta: PT Gramedia Pustaka Utama.

DePorter, B., \& Hernacki, M. (2005). Quantum Learning: Membiasakan Belajar Nyaman dan Menyenangkan. Bandung: Kaifa.

Djohan. (2016). Psikologi Musik (Edisi ke 4). Yogyakarta: Galang Press.

Hidayat, S. (2011). Pengaruh Musik Klasik Terhadap Daya Tahan Konsentrasi Dalam Belajar. Skripsi. Fakultas Psikologi Universitas Islam Negeri Sultan Syarif Kasim Riau.

Kartono, Kartini. (1996). Psikologi Umum. Bandung: MajuMundur.

Lawrence, D. L. (2001). Using Music In The Classroom. Finglas Business Park, Tolka Valley Road, Finglas, Dublin 11. 01-808-1494. PastPapers.ie.

Murrock, C. J. (2005). Chapter 8 Music And Mood. Doctoral Student University of Akron. Journal Sains.

Lane, Andrew, M., Whyte, Greg., George, Keith., Shave, Rob., Steven, Matthew., and Barney, Sam. (2007). Chapter 14 marathon: a fun run? Mood state 
changes among runners at the London marathon. Pp. 261 - 270. ISBN: 1 - 60021 - 269 - 7. Mood And Human Performance: Conceptual, Measurement And Applied Issues. New York: Nova Science Publishers, Inc.

(Online), https://books.google.co.id/books?id=ZtH8wuKvSSQC\&printsec $=$ frontcov er\&dq=mood+and+human+performance+conceptual+measurement+and+a pplied+issues\&hl=id\&sa $=$ X\&ved=0ahUKEwjUj4qCu5PaAhUXSo8KHW GBB4UQ6AEIKDAA\#v=onepage $\& \mathrm{q}=\operatorname{mood} \% 20$ and $\% 20$ human $\% 20$ perfo rmance \%20conceptual\%20measurement\%20and\%20applied\%20issues\&f =false. Diakses pada tanggal 10 Desember 2017.

Latipun. (2010). Psikologi Eksperimen (Edisi Kedua). Malang: UMM Press.

Robbins, S. P., \& Judge, T. A. (2012). Organizational Behavior $15^{\text {th }}$ ed. New Jersey: Pearson Education, Inc.

Sulastianto, Harry dkk. (2006). Seni dan Budaya. Bandung: PT Grafindo Media Pratama,

(Online), http://books.google.co.id/books?id=oyBkVHuQWylC\&pg=PA141\&dq=m usik+klasik+adalah\&hl=id\&sa=X\&ved=0ahUKEwi7zYhqpPaAhVCso8K HU5zCxk4FBDoAQgcMAQ\#v=onepage\&q=musik\%20klasik\%20adalah $\underline{\& \mathrm{f}=\text { false. }}$. Diakses pada tanggal: 14 Desember 2017.

Supradewi, R. (2010). Otak, Musik, Dan Proses Belajar. Fakultas Psikologi Universitas Gajah Mada. ISSN: 0854-7108. Vol. 08 no. 2.58-68. Jurnal Buletin Psikologi.

Watson, D. (2015). Mood And Temperament. New York: The Guildford Press. (Online), https://books.google.co.id/books?id=iPFboulhcQcC\&printsec=frontcover $\& \mathrm{dq}=$ mood $\& \mathrm{hI}=\mathrm{id} \& \mathrm{sa}=\mathrm{X} \& \mathrm{ved}=0 \mathrm{ahUKEwjbn5Pt}-$ 4nYAhWGnZQKHa0LBxlQ6AEIDDAA\#v=onepage $\& \mathrm{q}=$ moods $\& \mathrm{f}=$ false. Diakses pada tanggal: 14 Desember 2017.

Widhyatama, Sila. (2012). Sejarah Musik Dan Apresiasi Seni. Jakarta Timur: PT Balai Pustaka.

(Online), https://books.google.co.id/books?id=IRZ9DQAAQBAJ\&pg=sejarah+musi

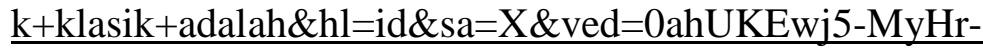
3XAhXEr48KHeusBKEQ6AEIDzAB\#v=onepage $\& \mathrm{q}=$ sejarah $\% 20$ musik\% 20klasik\%20adalah\&f=false. Diakses pada tanggal 04 Desember 2017. 